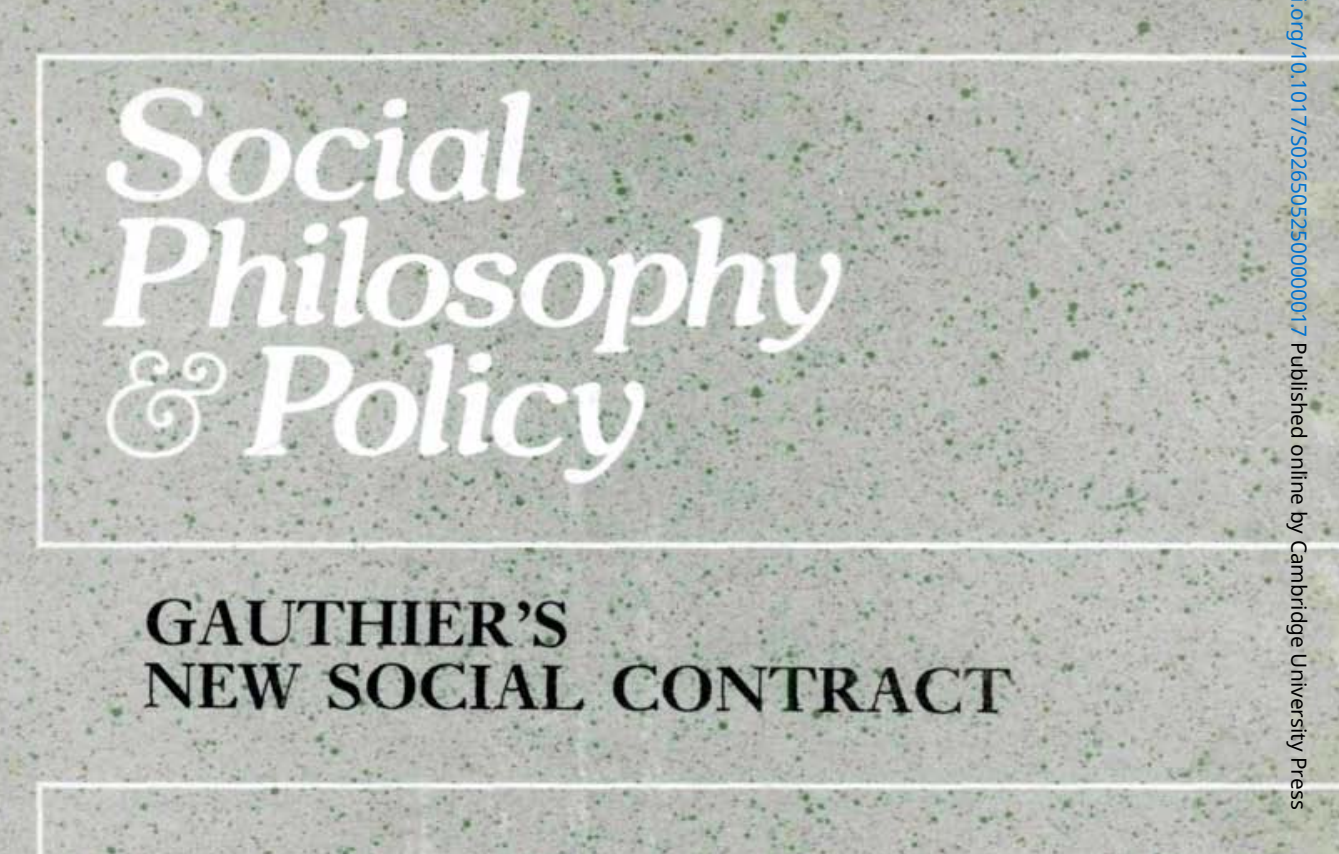

\title{
Contributors
}

\section{GILBERT HARMAN}

KURT BAIER

JAMES S. FISHKIN

RUSSELL HARDIN

JAMES M. BUCHANAN

EDWARD F. MCCLENNEN

CHRISTOPHER W. MORRIS

LAURENCE THOMAS

DAVID GAUTHIER
Rationality in Agreement: A

Commentary on Gauthier's

Morals by Agreément

Rationality, Value and

Preference

Bargaining, Justice, and

Justification: Towards

Reconstructión

Bargaining for Justice

The Gauthier Enterprise

Constrained Maximization and

Resolute Choice

The Relation between

Self-Interest and Justice in

Contractarian Ethics

Rationality and Affectivity: The Metaphysics of the Moral Self Morality, Rational Choice, and Semantic Representation: A Reply to My Critics 
Social

Philosophy

E̊Policy

ISSN 0265-0525
Edited at the Social Philosophy and Policy Center

Bowling Green State University

Bowling Green, Ohio 43403, USA

(C) Social Philosophy \& Policy 1987

Editor Ellen Frankel Paul

Associate Editors

Managing Editor
Fred D. Miller, Jr. Jeffrey Paul John Ahrens

\section{Editorial Board}

David Braybrooke

Dalhousie Eniversity

Baruch Brody

Rice Liniversity

James Buchanan

Centre for Study of Public Choice,

George Mason Linicersity

Jules Coleman

Yale Lniversiny

Maurice Cranston

London School of Economic

Jack Douglas

University of Califormia,

San Diego

Richard Epstein

University of Chicago, Law School

Antony Flew
Social Philosophy' and Poligy Cen
Charles Fried
Harvard Law School
Martin Golding
Duke Unicersity
John Gray
Jesus College, Oxford University
Gilbert Harman
Princeton University
William Kristol
Kennedy School, Harvard
University
Seymour Martin Lipset
Stanford Lniversity
Eric Mack
Tulane Unicersity

Antony Flew

Harvey Mansfield

Hariard University

Wallace Matson

Unversity of Califormia, Berkeley

Jan Narveson

University of Waterloo

Robert Nozick

Harvard University

Nicholas Rescher

University of Pittsburgh

David Sidorsky

Columbia University

Hillel Steiner

University of Manchester

James Q. Wilson

UCLA

Leland B. Yeager

Aubum University

\section{SUBSCRIPTIONS for Vol. 5 (1988-9)}

Orders, remittances and subscription enquiries should be addressed to:

Journals Department, Basil Blackwell Ltd., 108 Cowley Road, Oxford OX4 1JF, England

Published twice yearly in Autumn and Spring

\begin{tabular}{|c|c|c|c|c|}
\hline & & USA, & & Make checks, drafts etc, payable to: \\
\hline & UK & $\begin{array}{l}\text { Canada } \\
\text { \& Japan }\end{array}$ & Other* & LID. \\
\hline Institutions & $£ 29.00$ & $\$ 50.00$ & $£ 36.00$ & \\
\hline Individuals & 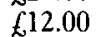 & $\$ 13.60$ & 616.35 & *includes Eire \\
\hline Single Issues & $£ 7.00$ & $\$ 9.60$ & $£ 7.50$ & \\
\hline
\end{tabular}

Back issues are available from the publisher at the current single copy rate.

Issues on Microfilm: An arrangement for the supply of microfilm copies of Social Philosophy \& Policy from Volume 1 onwards, has been made with University Microfilms International, Dept. P.R., 30-32 Mortimer Street, London W1N 7RA, England; 300 North Zeeb Road, Ann Arbor, Mi. 48106, USA. 


\section{CONTRIBUTORS}

Gilbert Harman is Professor of Philosophy at Princeton University, where he is Chairman of the Committee for Cognitive Studies. With George Miller, he runs the Princeton Cognitive Science Laboratory. He is the author of Change in Viem: Principles of Reasoning (1986), The Nature of Morality: An Introduction to Ethics (1977), and Thought (1973). He is also the editor of On Noam Chomsky (1974), and, with Donald Davidson, of Semantics of Natural Languages (1972) and The Logic of Grammar (1975).

Kurt Baier is Distinguished Service Professor of Philosophy at the University of Pittsburgh. He received his D.Phil. from Oxford University in 1952, and has taught philosophy at the University of Melbourne and The Australian National University. He is a past President of the Eastern Division of the American Philosophical Association. Professor Baier is the author of The Moral Point of Viem (Cornell University Press, 1958) and coeditor, with Nicholas Rescher, of Values and the Future (The Free Press, 1969).

James S. Fishkin is Professor of Government and Philosophy at the University of Texas at Austin and a Fellow of the Center for Advanced Study in the Behavioral Sciences at Stanford. He holds a Ph.D. in philosophy from Cambridge University and a Ph.D. in political science from Yale University. Professor Fishkin is Associate Editor of Ethics, and the author of Tyranny and Legitimacy (Johns Hopkins University Press, 1979), The Limits of Obligation (Yale University Press, 1982), 7ustice, Equal Opportunity and the Family (Yale University Press, 1983), and Beyond Subjective Morality (Yale University Press, 1984).

Russell Hardin is Mellon Foundation Professor of Political Science, Philosophy, and Public Policy Studies at the University of Chicago. He is the author of Morality within the Limits of Reason (University of Chicago Press, forthcoming), and Collective Action (Johns Hopkins University Press for Resources for the Future, 1982), and the editor of Ethics: An International Journal of Social, Political and Legal Philosophy. His articles on rational choice, moral and political philosophy, and nuclear weapons policy have appeared in many journals and books. 


\section{CONTRIBUTORS}

James Buchanan is Hobart L. Harris University Professor and General Director of the Center for Study of Public Choice at George Mason University, and the recipient of the 1986 Nobel Prize for Economics. Professor Buchanan received his Ph.D. from the University of Chicago in 1948 and has taught economics at Virginia Polytechnic Institute and State University, the University of California at Los Angeles, the University of Virginia, and Florida State University. He is the author of numerous books on economics and public policy, including Fiscal Theory and Political Economy (University of North Carolina Press, 1960), Demand and Supply of Public Goods (Rand-McNally, 1968), and The Limits of Liberty: Between Anarchy and Leviathan (University of Chicago Press, 1975).

Edward F. McClennen teaches at Washington University in St. Louis. He has published numerous articles on topics in decision and game theory, social choice theory, and social and political philosophy. In 1984, he served as Director of a Summer Institute on Public Choice Theory, sponsored by The Council for Philosophical Studies. His book, Rationality and Dynamic Choice: Foundational Explorations, is forthcoming from Cambridge University Press. He is currently working on a second book which deals historically and analytically with the concept of rational self-interest and its relevance for the justification of moral principles.

Christopher Morris is Professor of Philosophy at Bowling Green State University. Professor Morris received his Ph.D. in philosophy from the University of Toronto in 1977, and has taught philosophy at the University of California at Riverside, the University of California at Los Angeles, the University of Montreal, the University of Ottawa, and the University of Toronto. He has published numerous scholarly articles and reviews in such journals as Ethics, the American Philosophical Quarterly, the Fournal of Social Philosophy, and the American Political Science Reviem.

Laurence Thomas is Professor of Philosophy at Oberlin College. He has taught philosophy at the University of North Carolina at Chapel Hill, the University of Maryland, Notre Dame University, and Harvard University. Professor Thomas has published numerous scholarly essays in such journals as the Canadian Fournal of Philosophy, the American Philosophical Quarterly, the Personalist, and the Fournal of Value Inquiry.

David Gauthier is Distinguished Service Professor of Philosophy at the University of Pittsburgh. The relationship of reason and morality has long been his primary intellectual concern, and provides the theme of Morals by Agreement. Having shown, as he continues to believe, that moral constraints have firm roots in rational agreement, he now hopes to explore the underlying account of reason, and the standard of rationality, that are presupposed by the theory of rational choice. 